\title{
Nonossifying Fibromyxoid Tumor
}

National Cancer Institute

\section{Source}

National Cancer Institute. Nonossifying Fibromyxoid Tumor. NCI Thesaurus. Code C6583.

A rare soft tissue tumor of uncertain lineage characterized by the presence of neoplastic spindle to round cells forming cords in a fibromyxoid stroma. Metaplastic bone formation is not present. 